\title{
Effect of chitosan coatings on the physicochemical characteristics of Eksotika II papaya (Carica papaya L.) fruit during cold storage
}

\begin{abstract}
The effect of chitosan on the physicochemical characteristics of Eksotika II papaya fruit stored at $12 \pm 1{ }^{\circ} \mathrm{C}$ and $85-90 \%$ relative humidity, was investigated. Chitosan provided an effective control in reducing weight loss, maintained firmness, delayed changes in the peel colour and soluble solids concentration during 5 weeks of storage. The titratable acidity declined throughout the storage period, though at a slower rate in the chitosan coated fruit as compared to the control. Sensory evaluation results also confirmed the efficacy of chitosan. Consequently, the internal gaseous concentrations of $\mathrm{CO} 2$ and $\mathrm{O} 2$ also proved the usefulness of chitosan. These findings suggest that chitosan can be used commercially for prolonging the storage life of Eksotika II papaya fruit.
\end{abstract}

Keyword: Chitosan, Gaseous exchange, Papaya, Postharvest quality, Sensory evaluation 